\title{
Current situation and future prospects for beef production in Thailand - A review
}

\author{
Thanaporn Bunmee ${ }^{1, a}$, Niraporn Chaiwang ${ }^{2, a}$, Chonlathee Kaewkot ${ }^{3, a}$, and Sanchai Jaturasitha ${ }^{3, a, *}$
}

* Corresponding Author: Sanchai Jaturasitha Tel: +66-81-951-2536, Fax: +66-53-357601,

E-mail: ja.sanchai@gmail.com

1 Division of Animal Sciences, School of Agriculture and Natural Resources, University of Phayao 56000, Thailand

${ }^{2}$ Department of Agricultural Technology and Development, Faculty of Agricultural Technology, Chiang Mai Rajabhat University 50300, Thailand ${ }^{3}$ Department of Animal and Aquatic Sciences, Faculty of Agriculture, Chiang Mai University 50200, Thailand

a These authors contributed equally to this work.

ORCID

Thanaporn Bunmee

https://orcid.org/0000-0001-8117-0690

Niraporn Chaiwang

https://orcid.org/0000-0001-8220-7256

Chonlathee Kaewkot

https://orcid.org/0000-0001-8453-8905

Sanchai Jaturasitha

https://orcid.org/0000-0003-0762-3748

Submitted Mar 14, 2018; Revised May 14, 2018; Accepted May 24, 2018

\begin{abstract}
Thailand is a country of native beef cattle resource farming. It has undergone rapid social and economic change in the past decade. Agricultural growth has been maintained by increasing the production of rice and cassava. Changing economic status also provides opportunities for beef cattle producers to meet increasing consumer demand for beef. Finishing beef cattle numbers in Thailand were about 1.0 M head in 2015. Beef produced in Thailand has exclusively been for domestic consumption. Only $1 \%$ of Thailand's beef cattle are for the premium market which is based on marbling score, $40 \%$ are sold into modern markets that consider muscling of cattle, and the remainder enter traditional markets. Cross-bred cattle for the premium market are raised within intensive systems. Most producers of premium beef are members of beef cooperatives, or have invested in their enterprises at high levels. Culled cow (native or cross-bred cattle) are mainly for small holder farm production. Malaysia, Indonesia, and other members of the Asian Economic Community (AEC) are set to become the largest beef market, which has been confirmed by 2015 through 2020 forecasts for consumption of beef that must increasingly be halal. These circumstances are likely to be challenging for beef producers in Thailand to gain a share of this market. Integration across all sectors involved in beef production in Thailand will be required.
\end{abstract}

Keywords: Beef Production; Beef Market; Culled Cow; Consumption; Agriculture

\section{INTRODUCTION: AN OVERVIEW OF THAILAND AND ITS AGRICULTURE}

In a transitional country such as Thailand, the livestock sector is undergoing highly dynamic changes. This has resulted from rapidly increasing demand for meat and meat products. The changes in the demand for livestock products have been driven by income growth, urbanization and educational background. Demand for livestock products in the future could be heavily moderated by socio-economic factors such as human health concerns and changing socio-cultural values. The differential livestock system in Thailand has been associated with scientific and technological developments and increases in efficiency and environmental sustainability. In the future, the livestock production systems will encounter competition for natural resources, climate change and food, feed and fuel competition. Developments in breeding, nutrition and animal health will primarily target adaptation, production potential and further improvements in efficiency including through genetic selection programs.

Thailand is a newly industrialized country. Its economy is heavily export-dependent with exports accounting for more than two-thirds of its gross domestic product (GDP). The industrial and service sectors are the main sectors contributing to the Thai GDP, with the former accounting for $39.2 \%$ of GDP. Thailand's agricultural sector produces $8.4 \%$ of GDP lower than the trade and logistics and communication sectors. Thailand is a tropical coun- 
try in South-east Asia that generally has high temperature and humidity. From a meteorological point of view, the climate of Thailand may be divided into three seasons: rainy, cool and summer. Thailand is covered by warm and moist air in most periods of the year except for areas further inland for which the relative humidity may significantly lower in the cool and dry season. The Southern part of the country is maritime and the humidity is higher [1].

Agriculture in Thailand is highly competitive, diversified and specialized, and its exports are very successful internationally. Agricultural production as a whole accounts for an estimated $9 \%$ to $10.5 \%$ of Thai GDP, and $40 \%$ of the population works in agriculture-related jobs. Rice is the country's most important crop. Thailand is a major exporter in the world rice market, and rice contributed $1.3 \%$ of GDP in 2014. Thailand is a leading producer and exporter of rice, rubber, canned pineapple and black tiger prawns, and is seeking to expand its exports of livestock products, especially of chicken meat. The GDP from the livestock industry in Thailand is expected to grow at $1.5 \%$ to $2.5 \%$ per annum [1]. Cassava plantations covered $14,080 \mathrm{~km}^{2}$ in $2015 / 16$, production about 33 million tons of starch annually. The largest area of cassava plantations in Thailand are in the North-east region. The Northern region is an area of hills and mountains with only $10 \%$ lowland. The predominant activity is one rain-fed rice crop per annum, with some upland crops such as cassava, sub-tropical fruit and livestock predominantly comprising cattle and Thai native chicken.

The North-east of Thailand is an area of traditional beef cattle farming. This region has undergone rapid physical, social and economic change in the past decade. Agricultural growth has been maintained by increasing the production of rice and cassava, and more rapid growth in beef production. The Central region is the most fertile, and largely comprises irrigated river flats where rice and other crops are grown on the vast, wet alluvial plains around the Chao Phraya River. The Office of Agricultural Economics annually conducts surveys of major crops including rice in 2017 through 2018. Livestock and poultry production is currently of two major types: large commercial farms and backyard non-commercial farms. The predominant types of livestock are beef cattle, buffalo, swine, chicken, and dairy cows. The South is predominantly a lowland rubber, coconut and palm growing region. This area has the majority of the Muslim population within Thailand and the highest concentration of small ruminants such as sheep and goats.

\section{AN OVERVIEW OF BEEF CATTLE PRODUCTION IN THAILAND}

Live cattle price in Thai local markets fell from 2007 to 2009, reducing the profitability of cattle rearing and many cattle farmer left the business. As a result, a large number of cows were slaughtered and calf production also decreased from 2007 to 2009. In addition, strong demand for beef cattle from China and Vietnam resulted in Thailand becoming an exporter of cattle including breeding cows, and also a transit country for cattle movement from Myanmar to China and Vietnam [2].

The beef cattle population in Thailand is currently about 4.9 million head, [1]. About 1.0 million head of beef cattle are slaughtered annually. Beef cattle are mainly in the North-east (48\%), with $16 \%$ in Northern area and $12 \%$ in Southern area. The greatest proportionate increase has occurred in the Southern and Northern regions, where cattle numbers have increased by $11.5 \%$ and $7.7 \%$, respectively [3].

Beef cattle in Thailand can be classified into three groups according to their genetic types [4]. The first group is Thai native cattle which make up $61 \%$ of the population, although they have been decreasing in number by $0.7 \%$ annually. Native cattle in Thailand have characteristics of Bos indicus (Zebu), including the distinctive dorsal hump. There are four native breeds officially recognized by the Department of Livestock Development: Kho-KhaoLamphun (Northern Thailand), KhoIsaan (Northeastern Thailand), Kho-Lan (Central Thailand), and Kho-Chon (Southern Thailand). These breeds may have originated from different regions of Thailand [5]. Beef productivity of native cattle is low because of their slow growth rate, small size, and low carcass yields. Live weight at 24 months is only 150 to $200 \mathrm{~kg}$ for heifer and 200 to $250 \mathrm{~kg}$ for steer. The average meat yield is also low (32\% to $33 \%$ ) or 50 to 60 $\mathrm{kg} / \mathrm{head}[6]$. These Thai cattle are well adapted to the tropical environment, with good heat tolerance and resistance to ectoparasites $[7,8]$, are also well-adapted to utilize agricultural by-product or low quality feeds, and have high fertility and good mothering ability [9]. The second most numerous group are Brahman and Brahman crossbreeds (35\% of the population). Both breeds are used in a production system with natural grassland and agricultural by-product supplementation, resulting in body weight gains during the rainy season (MayNovember) and loss of body weight during the dry season (December-April). The third major group is fattening beef cattle. Thai native and Brahman-cross cattle have been hybridized with imported Bos taurus beef breeds, resulting in a higher performance crossbred cattle population that is growing in number. These cross-bred cattle are well adapted to the local environment but grow slower and have lower productivity than pure Bos taurus beef breeds [7].

Traditionally rearing of beef cattle has been cooperative with rice field activity, but a doubling of cropping for rice production has reduced the grazing area available for cattle. A lack of natural grasslands limits large-scale beef production in Thailand. Various attempts have been made to create pastoral lands for cattle, and recently many of these grazing systems have been leased for beef cattle production, especially for cowcalf production. Nevertheless, the production and price of crops in past decade years have declined [10]. At the same time, 
rural borrowing has increased leading to financial difficulties for many households. The government has attempted to diversify agricultural production away from off-season rice and other conservative crops towards more intensive and high value agricultural activities. One of diversification activities is beef cattle farming to meet the increasing demand for beef from urban consumers. Changing patterns of land use and social and economic conditions are altering the way in which cattle are farmed. Cattle now have less access to common grazing land and are increasingly farmed in cut-and-carry systems. Which regard to the main feed source for the cattle, in general finishing cattle production is common in systems based on grain and/or agricultural by-products such as cassava chip, cassava pulp, and corn silage.

Thailand was an importer of beef cattle until 2008 due to domestic production being unable to meet local demand. Thus, cattle moved from Myanmar to Thailand to meet domestic demand. However, since 2008, the direction of cattle flows has been reversed due to strong demand for beef cattle from China and Vietnam [2]. Thailand has also become a transit country for cattle movement between Myanmar and China or Vietnam (Table 1).

\section{BEEF CATTLE REARING SYSTEMS IN THAILAND}

\section{Cow-calf system}

Generally, most Thai native cattle are used in beef production as parent breeding stock for cow-calf production. The female native cattle (heifers or cows) are mated naturally or by artificial insemination, often to different sire-breeds to enhance performance. According to the Thailand Department of Livestock Development [11], there has been increasing interest in development of improved breeds such as the "Thai Black" which comprises Thai native cattlexBlack Angus and is suitable for Thai conditions, and, Charolaise-crossbred and Simbrah. Notwithstanding, efficiency in beef production is low due to low conception rates, delayed estrus and poor growth.

Generally, cow-calf operations raise their stock primarily on pasture and other forms of roughage, rather than grainbased concentrate feeds. Cattle manure is used to maintain soil fertility in rice production [12]. Cow-calf producers in agricultural areas commonly possess 2 to 10 cows which are fed in a cut-and-carry system or grazed on communal lands and supplement with a small amount of concentrate feed. Calves are raised and kept for various reasons. They may be kept for sale as a young animal at about 1 to 1.5 years of age, or enter a fattening system. The average income from cattle can be divided into two sections: the 1 to 1.5 year-old calf; and male cattle reared for 3 to 4 years. Cows in cow-calf systems have their first calf at around 30 to 40 month of age on average. The price of cattle depends on the breed and live weight. Reproduc- tion is the most important factor in determining profitability in a cow-calf system. To maintain a calving interval of 365 day, a cow must rebreed within 80 to 85 days after calving.

There is little incentive for the development of commercial beef farms because of scarcity of land and the high levels of investment required. The Department of Livestock Development offers loans of about $\$ 7,000$ with no repayments for three years [4], and Achmad et al [13] suggested the need for government intervention to develop and expand beef cattle programs through incentives and policy support.

\section{Stocker (steer) cattle system}

Stocker systems for steers and yearling bulls use animals averaging between about 180 (weaned calves) and $350 \mathrm{~kg}$ live weight, and are common practice in beef production in the Northern region of Thailand. The stocker system supplies cattle for finishing. Ranchers often graze their cattle on fallow land, crop fields after harvesting, and on natural communal land. In the rainy season, natural grasses grow well and can provide enough feed for cattle without the need for supplementation. Grazing lands are mainly (80\%) communal lands, the remainder being the farmers own land or roadsides. In some cases, the cattle are grazed on mountains especially during the rainy season. In the Southern areas, the cattle graze in rubber and palm oil plantations. In the dry season, low humidity inhibits the growth of natural forage plants leading to a severe shortage of feed resources. During this season, supplements of rice straw and agricultural by-products such as pineapple by-product, palm kernel and cassava pulp are of major importance. Nevertheless, on-going research is investigating ways to better utilize existing resources strategically through simple, low cost, and integrated approaches. For example, research by Alemayehu [14] on improving the availability and quality of feed resources available to small-scale livestock producers during the dry season, demonstrated that techniques such as urea treatment, chopping and mixing of crop residues with high quality forages can improve their intake and dietary quality significantly. Similarly, Firew et al [15] reported that urea-treatment improved crude protein content of wheat straw from $2.7 \%$ to $8.7 \%$ and apparent dry matter digestibility from $55 \%$ to $65 \%$ resulting in significantly increased total feed intake. Also, ranchers have started to plant pasture on unused land or instead of rice [9]. Jasmal et al [16] proposed using rice straw as a ruminant feed resources to enhance regional livestock development. Cattle may graze with no supplementation; however supplementation is required to support growth of muscle and fat for higher yielding animals. Consequently, crop residues, corn husks, rice bran, and brewers grains play an important role in these systems. Napier grass is the fodder crop of choice and is widely grown in less productive areas for higher productivity as feed for cattle. In this regard, Tudsri et al [17] showed that Napier grass produces higher dry matter yields than Ruzi. 
Table 1. Livestock statistic in Thailand from 2015 to 2017

\begin{tabular}{|c|c|c|c|c|}
\hline Description & 2015 & 2016 & 2017 & Changing rate from 2015 to 2017 (\%) \\
\hline \multicolumn{5}{|l|}{ Number of cattle } \\
\hline Native cattle (Head) & $2,742,421$ & $2,702,299$ & $2,813,223$ & 2.52 \\
\hline Crossbred cattle (Head) & $1,387,690$ & $1,533,002$ & $1,904,783$ & 27.15 \\
\hline Fattening cattle (Head) & 159,312 & 171,807 & 158,222 & -0.69 \\
\hline \multicolumn{5}{|l|}{ Beef production } \\
\hline Total animal (Head) & 890,000 & 916,000 & 962,000 & 7.48 \\
\hline Weigh of carcass (Ton) & 149.54 & 154.03 & 161.73 & 7.54 \\
\hline Selling price $(\$ / k g)$ & 3.33 & 3.28 & 3.05 & -9.18 \\
\hline \multicolumn{5}{|l|}{ Total domestic consumption } \\
\hline Total animal (M.Head) & 1.26 & 1.26 & 1.268 & 0.16 \\
\hline Weigh of carcass (Ton) & 211.34 & 211.51 & 211.68 & 0.16 \\
\hline \multicolumn{5}{|l|}{ Beef export } \\
\hline Live animal (Head) & 204,857 & 227,172 & 161,000 & -27.24 \\
\hline Total values $(\$)$ & 55.9 & 33.9 & 66.6 & 16.07 \\
\hline Average price per head $(\$)$ & 273.04 & 131.51 & 413.68 & 34.00 \\
\hline Meat and meat product (Ton) & $2,462.82$ & 172.09 & 119.23 & -72.67 \\
\hline Total values $(\$)$ & 8.06 & 1.03 & 1.13 & -62.57 \\
\hline Average price per kilogram (\$) & 3.27 & 5.54 & 9.47 & 65.47 \\
\hline \multicolumn{5}{|l|}{ Beef import } \\
\hline Live animal (Head) & 130,260 & 101,507 & 121,530 & -11.9 \\
\hline Total values (\$) & 59.1 & 50.8 & 54.6 & 15.81 \\
\hline Average price per head $(\$)$ & 454.41 & 498.34 & 449.96 & 31.39 \\
\hline Meat and meat product (Ton) & $10,314.90$ & $10,476.51$ & $12,503.00$ & -10.23 \\
\hline Total values $(\$)$ & 70.2 & 69.9 & 84.7 & 3.80 \\
\hline Average price per kilogram $(\$)$ & 6.81 & 6.68 & 6.77 & 15.64 \\
\hline
\end{tabular}

Source: [31]

\section{Cattle finishing system}

Cattle in finishing systems are provided with a specific fattening feeding regime in an intensive system to obtain a specific market weight for sale. Usually, the production cycle from birth to market for finished cattle averages 3 years. The number of cattle per feedlot ranges from 10 to 600 head.

Cattle are fed high-energy concentrates and rice straw or roughage. Normally they are fed a ration with a 70:30 concentrate to roughage ratio [18] for 8 to 12 months to reach 550 to $600 \mathrm{~kg}$ body weight [19]. The main feeds consist of carbonaceous concentrate which accounts for between $60 \%$ to $80 \%$ of production costs depending on factors including season, farm location and intensiveness of production. Total mixed rations are formulated from a mixture of locally available feedstuffs and agricultural by-products; mostly cassava chips, byproduct from pineapple, rice straw, and dried brewers grains.

In general, while feed prices substantially impact on profitability, the relativity of input costs (stocker cattle costs, capital costs, and operating expenses) and output prices (fattening cattle prices or manure prices) impact more on profitability. However, higher growth performance as affected by breed, nutrition and management has a markedly enhances profitability. Several Bos taurus cross-breeds enter these systems including Angus or Charolais crosses. Tak and Kabinburix
Bos Taurus cross-bred cattle are commonly used in specialized and commercial fattening farms [20]. The Tak breed is named after the province where the breeding station on which it was developed is located. The Tak breed was developed from American Brahman (37.5\%) and Charolais (62.5\%) breeds. The Kabinburi breed was developed from German Simmental (50\%) crossed with Brahman (50\%) for enhanced heat tolerance, fertility and growth [21]. Moreover, the Thai Black or Angus-crossbred is one of the most popular breeds due to marbling potential and rapid growth rate. Brangus is also regularly used in finishing systems due to muscling and marbling capacity coupled with heat tolerance.

Commercial fattening systems that produce prime and high quality beef have only $1 \%$ market share. However, growing demand for beef from urban inhabitants is providing increasing opportunities for high quality beef from fattening systems and markets for cattle. Fattening of cattle is a highly profitable venture with high returns for producers. Hence, Thai ranchers are currently developing their agribusiness potential mostly using cattle fattening operations.

\section{BEEF MARKETS AND PROSPECT OF BEEF PRODUCTION IN THAILAND}


Traditional market

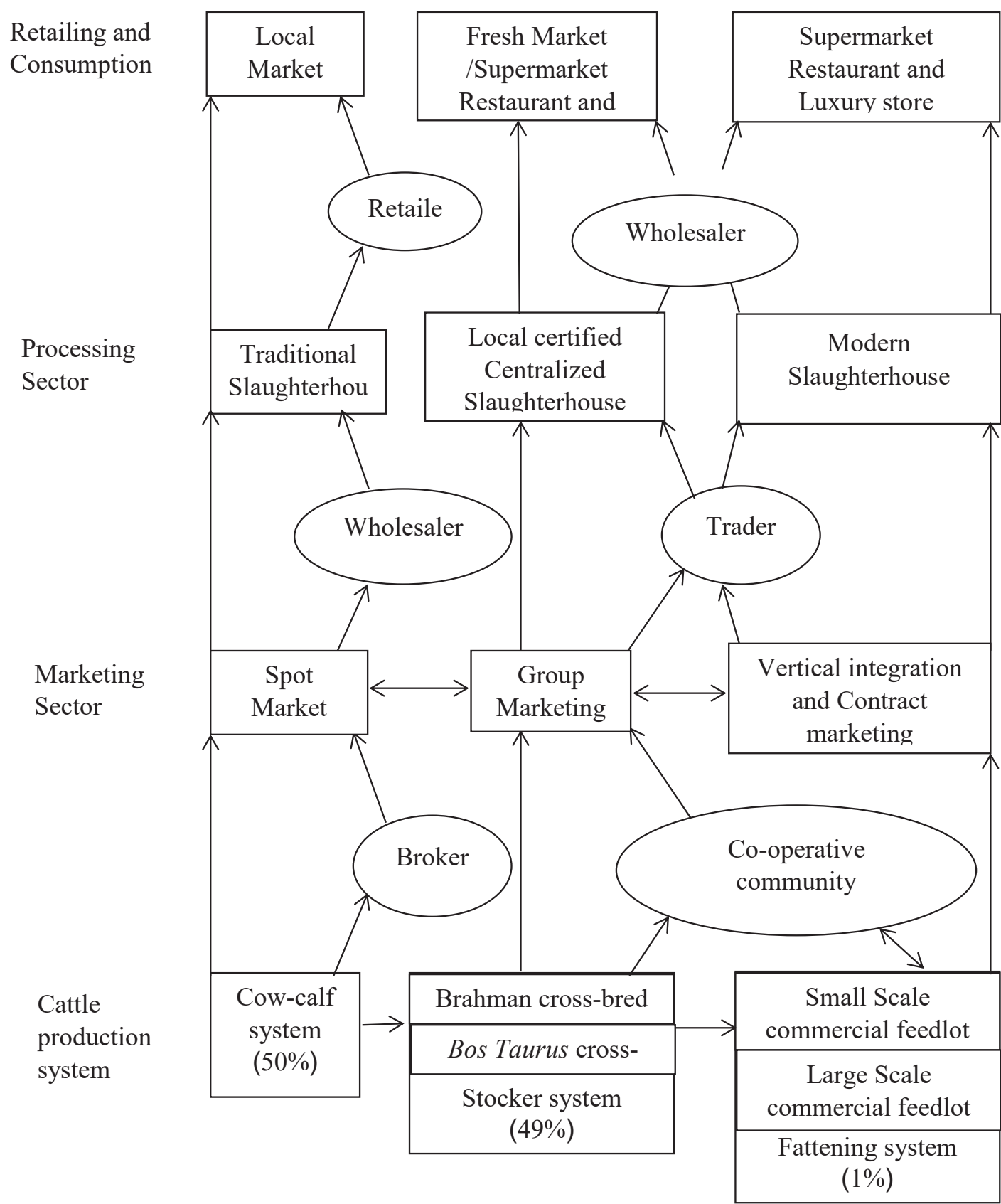

Figure 1. Cattle marketing and trade systems in Thailand [30].

Beef consumption in Thailand is about 170 thousand tonnes per year [22]. However, there are substantial levels of imports of high quality frozen beef from Australia and New Zealand. Food manufacturers that are either involved in the restaurant business or food processing trades purchase beef based on specific customer requirements and price. Similarly, household or retail consumer decisions to purchase beef are based on price and quality. Beef is an important source of nutrients including essential amino acids, protein and $\mathrm{B}$ vitamins and therefore should remain as a healthy choice of meat of Thai consumers [23]. There is growth in economic opportunities for beef cattle production, processing and marketing in Thailand, including enhanced productivity, product development, and promotion of meat products influencing consumer demand for meat. As education is becoming more accessible to the masses, more people are experiencing upward economic mobility and thus have more purchasing power for high quality beef. Many processors of beef in Thailand are trying to meet 
the demand for increased protein from animals by increasing marketing channels such as convenience stores or restaurant franchises, and involvement in the production of processed meat products. However, it has been found that the quality of domestic beef is generally sub-standard [24]. This is due to farmers having poor knowledge and understanding of beef cattle production practices to produce high quality product. Poor uptake of technology and extension information has also result in deficiencies in beef cattle production systems.

As described above, Thai beef production has undergone dramatic changes. Live cattle marketing and trading systems in Thailand are shown in Figure 1. The beef cattle markets in Thailand separate based on price and qualities of beef. They lack efficient operational structures that clearly identify the major stakeholders in the value chain, starting with primary producers in the cow-calf and stocker systems through to retail consumers. Beef cattle marketing includes the producers, buyers (middle man or trader) of live cattle, processors, wholesalers or distributors of beef, retailers, consumers, and more formal systems including groups or cooperative communities of cattle producers. Distributors source supplies of cattle for slaughter through traders who normally locate cattle. Most animals are still sold directly from the local farm and are traded to the next stakeholder in the supply chain. There is a need for development of market value-chain that ensures all stakeholders in the marketing chain have economic incentives for income generation.

\section{Traditional beef market}

Traditional producers often sell their cattle to a broker or middleman though an auction market with immediate paying. Culled and old cows are also sold in these markets. The market share for these market chains is about $50 \%$. In the spot market, sellers are commonly producers, brokers or middlemen, and speculators. Sellers pay a market ticket and obtain an animal health certificate from a local livestock officer. The buyers are required to obtain a livestock movement permit from the local livestock officer, and pay a fee when they move animals across provinces [25]. The price of cattle depends on age, conformation, and stage of animal within the production system. Buyers are usually wholesalers or slaughterhouse owners who slaughter cattle for retailers. Some buyers are ranchers who purchase stock for breeding or fattening. The Thai native and Brahman cross-bred producer normally provides cattle for household consumption and other low value markets which lack meat quality specifications. Numerous cattle are sold without finishing. As mention above, agriculture in Thailand is highly productive. There are many agricultural byproducts such as rice straw, cassava pulp and also agro-food by product e.g. pineapple peel. Cattle should be well fed with these by-products before selling to the market. Occasionally, culled or old cows are fattened for 3 to 4 months using agricul- tural by-products to increase body muscle and fat percentages [26]. Accordingly, the opening of the Kunming-Bangkok highway, between Yunnan (China) and Thailand, makes transport between these two countries more convenient and has promoted beef cattle trade from Thailand. Native cattle with large body score have great potential for export along the highway to a large market like the People's Republic of China (PRC). Chinese domestic beef consumption has increased substantially. Tenderness tends to be much less important to Chinese consumer, therefore marbling is not a necessary attribute.

\section{Mid-value beef market}

Mid-value beef is produced from Brahman and some Bos taurus cross-breeds. The market share for mid-value beef is $49 \%$. Cattle are traded from the stocker system producers to the slaughterhouse via a marketing group or cooperative community chain. The mid-value carcasses are sold in fresh markets, supermarkets and restaurants, and are priced according to consumer demand and product quality. The price for beef has risen by over 100\% from 2007 to 2015 as a result of strong growth in demand. The increase in price reflects this increase in domestic beef consumption [26]. To minimize the loss of potential beef sales, the cattle cooperative should operate feedlots for cattle. Producer participation will be an importance. The strength of mid- value beef market reflects the growing imbalance between expanding domestic consumption and production that cannot fully meet demand.

\section{Premium beef market}

Consumers in major urban centers are leading premium meat's growing demand. It has been shown that consumers will pay a premium for guaranteed tender beef products [27] and for that reason high quality tender beef is goal for producers of beef to increase profitability. High quality beef with high intramuscular content is produced in fattening farms and sold in supermarkets. The carcass is chilled and aged for 2 weeks to improve tenderness. The market share for this high quality beef has been only $1 \%$ of the market in Thailand. Cattle from the stocker system are fed for 8 to 12 month a high energy diet with low fibre content. As most producers lack access to capital and/or, cooperatives have been established to overcome mutual economic problems. Formal cooperation may include contracts between producers or participation of processing and marketing stakeholders. Many cooperatives in Thailand allow cattle producers to pool their cattle and also to look for other types of investment to enhance beef processing capacity. This is consistent with the findings of Prasititi [28] who recommended effective strategies to develop beef cattle production and marketing. These include improvements in technology to enhance production and processing systems, and development of agribusiness partnerships in production, 
processing and marketing systems.

Moreover, slaughterhouses charge a trader for slaughter of cattle on a fee per service basis ( $\$ 0.34$ per head) [29]. Cattle are slaughtered using tradition methods without use of modern equipment. There is no weighing of live cattle before slaughter, although meat, offal and bone is weighed before distribution to retailers. The government has allowed the private sector to establish small modern slaughterhouses in each sub-district under the monitoring of the veterinary section of the subdistrict or sanitation administration. There are 791 registered slaughterhouses of which 594 are municipal slaughterhouses and 197 are privately owned [30]. In addition, the Department of Livestock Development has accelerated this program to raise the standard for good manufacturing practices for slaughterhouses which were proclaimed on August, 2004. For high value beef markets, wholesalers purchase the whole carcass from the slaughterhouse or trader after slaughter and they manage their own cutting of beef carcasses and grading for meat quality for specific market requirements. The wholesaler distributes to restaurants and luxury stores.

There are a lot of limitations which are confronting beef production in Thailand. Consumer are also expressing concern about the production system from which the meat produced and demanding consistent high beef quality. These situations require producer to find technology transfer from research. Therefore, the challenge is to provide information and control of the beef production in order to meet environmental sustainability and ensuring economic return such as suitable management for animal welfare, utilization agricultural byproduct.

\section{CONCLUSION}

With regard to the process of urbanization and urbanism in Thailand and The Association of South East Asian Nations (ASEAN), it has been found that demand for meat and meat consumption is increasing rapidly.

There are several options open to the beef industry in Thailand that provide ground for optimism for industry development and growth that were discussed widely. They include formal production-marketing contracts for farming of beef cattle and strategic plans for beef agribusinesses that connect producers and meat processor by public-private partnerships. Moreover, the farmer networks should build up as beef production cooperatives whose members are well trained in business. There should be two types of farming systems breeder farms and fattening farms. There must be preparation to expand the business in the future to extend to slaughterhouses, processing plants as well as butchery. This must be the win - win situation for producers and consumers in Thailand.

\section{CONFLICT OF INTEREST}

We certify that there is no conflict of interest with any financial organization regarding the material discussed in the manuscript.

\section{ACKNOWLEDGMENTS}

The authors would like to thank Functional Food Research Center for Well-being, Chiang Mai University for financial support.

\section{REFERENCES}

1. Office of Agricultural Economics [Internet]. Bangkok, Thailand: Agricultural Statistics 2015 [cited $2017 \mathrm{Feb}$ 16]. Available from: http://www.oae.go.th/main.php?filename=index_EN

2. Bourgeois-Lüthi N. Beef cattle and buffalo trade patterns from Xieng Khouang province, Lao PDR to Vietnam in a rapidly evolving regional marketing context [master's thesis]. Agribusiness for Development, School of Oriental and African Studies. London, UK: University of London; 2010.

3. DLD National Animal Statistics. In: Development DOL, editor. Livestock Sector Brief: Thailand. Bangkok, Thailand: FAO; 2014.

4. DLD National Animal Statistics. In: Development DOL, editor. Bangkok, Thailand: Department of Livestock Development; 2015.

5. Wangkumhang P, Willantho A, Shaw PJ, et al. Genetic analysis of Thai cattle reveals a Southeast Asian indicine ancestry. Peer J 2015;3:e1318.

6. Yodsoi S, Chaiwang N, Yammuen-art S, et al. Meat quality of Mountainous and white Lamphun cattle compared to Brahman crossbred. Kaen kaset 41 Suppl. 2013;1:45-50 (in Thai).

7. Charoensook R, Gatphayak K, Sharifi AR, et al. Polymorphisms in the bovine $H S P 90 A B 1$ gene are associated with heat tolerance in Thai indigenous cattle. Trop Anim Health Prod 2012;44: 921-8.

8. Khamkwan D, Laepaijit Y, Vitoonpong E, Intaratham W. Estimated breeding value and genetic trend of growth traits in Southern indigenous cattle line from multivariate analysis. BAHGI e-journal 2012;2:1-14 (in Thai).

9. Opatpatanakit Y, Tunvisoottikul K, Sethakul J. Factors affecting carcass quality of Thai-French beef. In: Proceedings of 53rd International Congress of Meat Science and Technology; 2007 August 5-10: Beijing, China; 2007. pp. 125-6.

10. Office of Agricultural Economics [Internet]. Bangkok, Thailand: Agricultural Statistics 2014 [cited 2017 Feb 10]. Available from: http://www.oae.go.th/main.php?filename=index_EN

11. DLD National Animal Statistics. In: Development DOL. editor. Bangkok, Thailand: Department of Livestock Development; 2002. 
12. Lambertz C, Chaikong C, Maxa J, Schlecht E, Gauly M. Characteristics, socioeconomic benefits and household livelihoods of beef buffalo and beef cattle farming in Northeast Thailand. J Agric Rural Dev Trop 2012;113:155-64.

13. Achmad MH, Arifin B, Didu SM. Model policy design for the beef cattle development in South Sulawesi, 1st Annual International Inter-disciplinary Conference, Bogor Agricultural University, Indonesia, 2013; 2013 April 24-26. Azores, Portugal: European Scientific; 2013. p. 26-36.

14. Alemayehu M. Short communications in grass land development options. Eth J Anim Prod 2005;5:125-31.

15. Fiew T, Kijora C, Peter KJ. Effects of incorporating cactus pear (Opuntia ficus-indica) and urea-treatment of straw on the performance of sheep: Conference on International Agriculture Research for Development 2005; 2005 Oct 11-13; Berlin, Germany. pp. 1-6.

16. Jasmal AS, Hikmah MA, Ridwan M, Mawardi A. Asia analysis of sustainability status of integration of beef cattle and paddy with technology innovation of rice straw as feed and beef cattle manure as fertilizer and biogas. Environ Nat Resour J 2013;11: $1-16$.

17. Tudsri S, Jorgensen ST, Riddach P, Pookpakdi A. Effect of cutting height and dry season closing date on yield and quality of five napier grass cultivars in Thailand. Trop Grassl 2002;36: 248-52.

18. Bureau of Animal Nutrition Development [Internet]. Bangkok, Thailand: Department of Livestock Development; 2017 [cited 2017 Jan 15]. Available from http://nutrition.dld.go.th/nutrition

19. Yimmongkol S. Research and development projects on improvement of the potential use of dried cassava pulp and cassava leaf meal. In: Concentrate of feedlot cattle [dissertation]. Bangkok, Thailand: Kasetsart University; 2009.

20. Boonyanuwat K, Sirisom P, Putharatanung A. Improvement of beef cattle genetics provided increasing sustainability of beef cattle production and protein consumption in Thailand. In: FAO/IAEA International Symposium on Sustainable Improvement of Animal Production and Health 2009; 2009 June
8-11; Vienna, Austria. pp. 77-9.

21. Boonprong S, Choothesa A, Sribhen C, Parvizi N, Vajrabukka C. Productivity of Thai Brahman and Simmental-Brahman crossbred (Kabinburi) cattle in central Thailand. Int J Biometeorol 2008;52:409-15.

22. OECD: Meat consumption [Internet]. Paris, France; OECD Publisher; [cited 2016 Dec 18]. Available from: https://data. oecd.org/agroutput/meat-consumption.htm

23. Mann N. Dietary lean red meat and human evolution. Eur J Nutr 2000;39:71-9.

24. DLD National Animal Statistics. In: Development DOL, editor. Bangkok, Thailand: Department of Livestock Development; 2012.

25. Pham L, Smith D, Putsakum M, et al. The Thai beef industry. In: Regional Workshop on Beef Markets and Trade in Southeast Asian and China 2015; 2015 30th November - 3rd December, Ben Tre, Vietnam.

26. Bunmee T, Jaturasitha S, Chaiwang N, Kreuzer M, Wicke M. Utilization of agro-food industry by-products in the finishing of culled dairy cows: effects on meat quality. CMU J Nat Sci 2012;11:295-302.

27. Shackelford SD, Wheeler TL, Meade MK, et al. Consumer impressions of tender select beef. J Anim Sci 2001;79:2605-14.

28. Prastiti RA, Arip W. Blora, Indonesia: Jurnal SEPA; 2017 [cited 2017 Feb 26]. Agribusiness Development Strategies of Beef Cattle in Blora District. Available from: http://agribisnis.fp.uns. ac.Id

29. National Bureau of Agricultural Commodity and Food Standards Ministry of Agriculture and Cooperatives. Good Manufacturing Practice for Abattoir. Bangkok, Thailand. 2004. pp. 1-25.

30. Skunmun, P. The bovine hide industry in Thailand. Asian Agrihist 2014;18:153-66.

31. Annual report. Office of Agricultural Economics. Bangkok, Thailand: Office of Agricultural Economics, Ministry of Agriculture and Cooperatives; 2017. 